\title{
EFFECT OF PRE-SOWING TREATMENTS ON SEED GERMINATION OF $P$. eurycarpa AND $P$. khinjuk - KURDISTAN REGION
}

\author{
Honar SAfar Mahdi, Wajed Issam Hussein, Harikar M. SAlih ${ }^{*}$ and SAmi Mohamed Amin Ali Youssef** \\ *Dept. of Recreation and Ecotourism, College of Agriculture, University of Duhok, Kurdistan region, Iraq. \\ U** University of Montpellier-France.
}

(Received: October 29, 2017; Accepted for publication: December 28, 2017)

\begin{abstract}
In the new global economic botany, seed germination ecology has become a central issue for increasing the number of the edible plants both in natural forest, cultivated field and nurseries. In this context, there has recently been an increasing amount of literature on the important economical value of Pistachio tree species for human livelihood activities and developments. In Kurdistan Region as a part of Zagrosian area and from ethnobotanical standpoint, Pistachio tree species are considered as an important natural resource of income to rural Kurdish people. Nevertheless, the farmers are often confronted to the difficulties of the seed germination of Pistachio tree species and the debate continues about the best pre-treatment for improving their propagation. Therefore, the main objective of this research is to analyze the effect of pre-sowing treatments on seed germination of two wild Pistachio tree species (Pistacia eurycarpa and Pistacia khinjuk) in Kurdistan Region. These pre-sowing treatments include hot water (for 5, 10 and 15 minutes), sulphuric acid scarification (for 5, 10 and 15 minutes), water soaking (for 1, 2 and 3 days), fruit (seed with exocarp) and untreated seeds (control). The results showed that the best seed germination (35\%) was obtained from soaking in chemical scarification for 10 minutes for both pistachio species. While low germination rate (1\%) achieved from fruits with exocarp for $P$. khinjuk with only $1 \%$. On the other hand, the best seed germination for $P$. eurocarpa was obtained from soaking seeds in $\mathrm{H}_{2} \mathrm{SO}_{4}$ for 5 and 10 minutes (as $36 \%, 42 \%$ respectively). Meantime low germination rate was achieved from soaking seed in water for 2 and 3 days as $8 \%$ and $6 \%$ respectively. This research has been done to provide an alternative method for increasing the cultivation of (Pistacia eurycarpa and Pistacia khinjuk) seed germination in Kurdistan Region. Therefore, this study will serve as a base for future studies and investigations in issue of economic botany and improvement of the rural Kurdish livelihood activities.
\end{abstract}

KEYWORDS: Pistacia spp, Chemical scarification, Hot water, Exocarp, Stratification, Seedling growth, Seed germination.

\section{INTRODUCTION}

$\mathbf{P}$ istachio L. described by Linné in 1753, is a genus of deciduous trees and shrubs belonging to the family Anacardiaceae (a moderately family of about 600 species mainly distributed in warmer regions (i.e. tropical, subtropical, Mediterranean areas)).It contains about 20 taxa, native to subtropical and semiarid areas, the majority in Asia and the Mediterranean region, but one species extending into tropical Africa and another in Central America (Townsend and Guest, 1980; De Rougemont, 1989; Shahbaz, 2010). According to Flora of Iraq (Jeffrey, 1980), Pistacia genus is represented as a whole by 3 taxa for Iraq territories. They are Pistcia vera L. cultivated species; $P$. khinjuk Stocks natives species; P. eurycarpa Yalt. Native species; with the potential presence of some hybrid ones e.g. $P$. eurycarpa $P$. khinjuk. In Kurdistan Region territories, as a part of the Irano-Anatolianhotspot for biodiversity (Mittermeier et al., 2004; Youssef et al., 2015), these three Pistachio species are commonly founded in Irano-Anatolian region(Jeffrey, 1980).They occur widely in all Zagros mountain range (from SE Turkey to SW Iran throughout the NE Iraq (Kurdistan Region)) and foothills of Upper Mesopotamian (Shahbaz, 2010). In Zagrosian area context, these Pistachio trees have demonstrated a well adaptation to the harsh environmental conditions: poor soil, continental climate (the mean month temperature is up to $+40 \mathrm{C}^{\circ}$ in summer and $-10 \mathrm{C}^{\circ}$ in winter), 
and high anthropogenic pressure (RaederRoitzsch, 1969; Chaabouni and Gouta, 2002).

In the global economic botany approach, Pistachio tree species have become one of the central issues for human livelihood activities. In recent years, there has been an increasing amount of literature on the important economical value of Pistachio species, especially for their edible fruits, resins and antibiotic characteristics (Thakur and Rathore, 1991; Fatahi, 1996; Kaska, 2001; Padulosi and Hadj-Hassan., 2001; Sharifi, 2014). In Zagrosian area and from ethnobotanical standpoint, Pistachio species have various local uses by Kurdish people and considered as a profitable source of income to rural owners: Beside that the true Pistachio ( $P$. vera) is well known for its edible fruits, widely used as dessert and in confectionery. The two native pistachio species ( $P$. eurycarpa and $P$. khinjuk) also provide excellent evidences for living ethnobotanical activities in Kurdish societies (Townsend and Guest, 1980). Firstly, their edible wild fruits with coppery green color on drying, are collected in early autumn and then sold in traditional markets of Iraq through-out the year; Secondly, they provide excellent rootstocks for the for the cultivated true Pistachio.

In some Literatures, there some difficulties to propagate the seeds of Pistachio tree species. Their seeds are covered by hard coated; thus, the seed germination is difficult and low (Ellis et al., 1985; Isfendiyaroglu and Özeker, 2002, Acar and Ercisli., 2017). There are some pretreatments has been used to break this hard coat and encourage germination of seeds both kind of cold and normal stratification were improved germination of seeds (Crane and Forde, 1974, Acar and Ercisli., 2017).
Chaabouni and Gouta (2002) highlighted that and germination rate were improved by treating seeds with acid scarification for two hours. The germination rates of $P$. khinjuk seeds were achieved good germination after treating seeds by stratification (Kafkas and Kaska, 1998). Soaking seeds in Sulfuric acid (chemical scarification) were encouraged by (Dirr and Heuser, 1987). Moreover, Scarified and stratified seeds were recommended by (Cole, 1994). Treating seeds with $\mathrm{H}_{2} \mathrm{SO}_{4}$ was the best treatment that improved the germination of Pistachio seeds (Ellis et al., 1985; Dirr and Heuser, 1987; Cole, 1994; Mackay, et al., 1995; Kafkas and Kaska, 1998). Debate continues about the best treatment for improving the seed germination of wild Pistachio tree species. Therefore, the purpose of this research is to investigate the seed germination ecology of two wild Pistachio tree species $(P$. eurycarpa and $P$. khinjuk) in Kurdistan Region. This research seeks to analyze in details the physical dormancy breaking by exposing seeds to chemical scarification, cold and hot stratifications, and fruits with exocarp.

\section{MATERIALS AND METHODS}

\section{Research site}

The research was conducted at the field of College of Agriculture/ University of Duhok (Latitude: $36^{\circ} 51$ '32.39"N) and (Longitude: $\left.42^{\circ} 52 ' 58.95 " \mathrm{~F}\right)$ elevation (473m) (Figure 1). The study area categorized as a semi-arid region (Peel et al, 2007). Furthermore, the mean of temperature for 2015-2016 was $26{ }^{\circ} \mathrm{C}$ with precipitation $(386 \mathrm{~mm})$ that started on October and ended on May (Youssef et al, 2017).

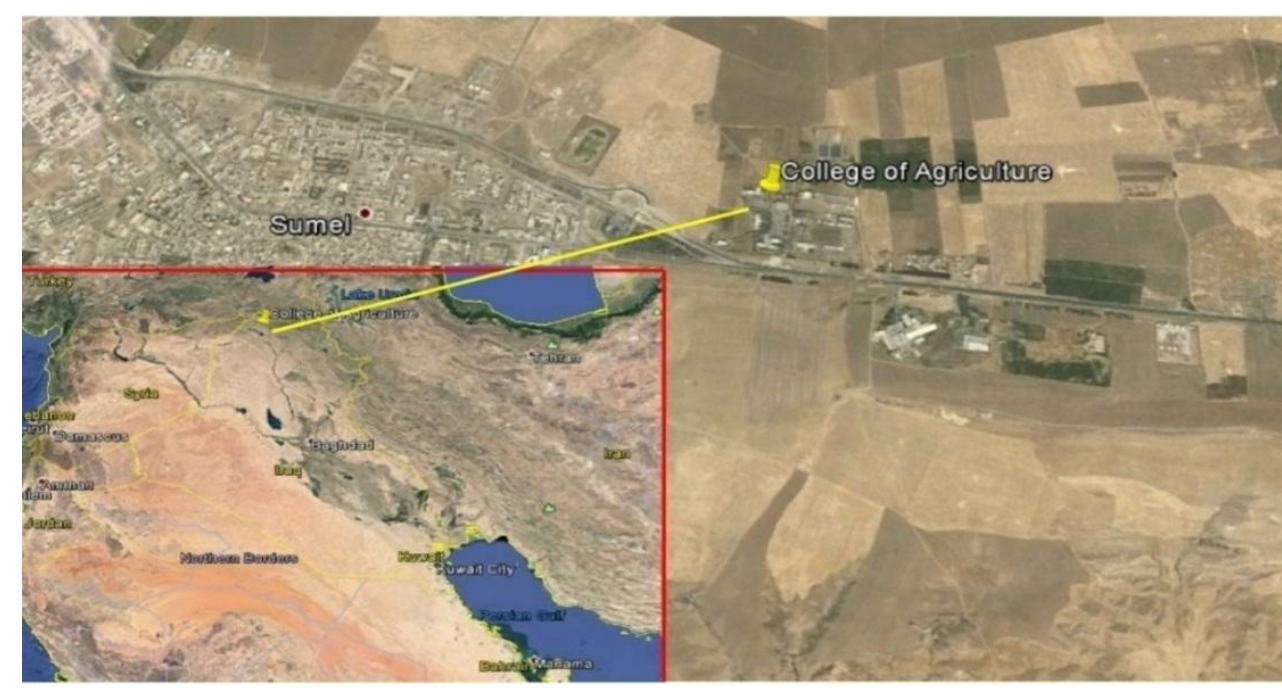

Fig. (1): Location of College of Agriculture Field in Duhok province - Kurdistan Region 


\section{Seeds collection and Treatment}

The seeds of pistachio were collected in October, 2014 from Mateen Mountain, Deralok District, Mergye Village (Latitude: $37^{\circ} 03^{\prime} 53.36^{\prime \prime} \mathrm{N}$ ) and (Longitude: 4341'57.67"E) elevation $(821 \mathrm{~m})$ (Figure 2), Duhok province, Kurdistan Region of Iraq as a native habitat according to Flora of Iraq. In this research three replication of seeds has been taken for hot water which were categorized to $5,10,15$ minutes soaking; sulfuric acid $\left(\mathrm{H}_{2} \mathrm{SO}_{4}\right)$ for 5 , 10 and 15 minutes; seeds soaking and the last treatment was 1, 2, and 3 days soaking in water and only one replication for fruit with exocarp, and four observation with 25 seeds sown for each observation which became 1100 in total. After seeds were treated with these treatments they were planted in black pots with (Diameter $24 * 21.8$ height) containing sandy soil at the field. The seeds were germinated counted starting on February2015 to the end of May on the daily bases. Seedling emergence count data were collected every week during the sown process. When the shoot of the seedling came above the ground considered as a seedling emerged.

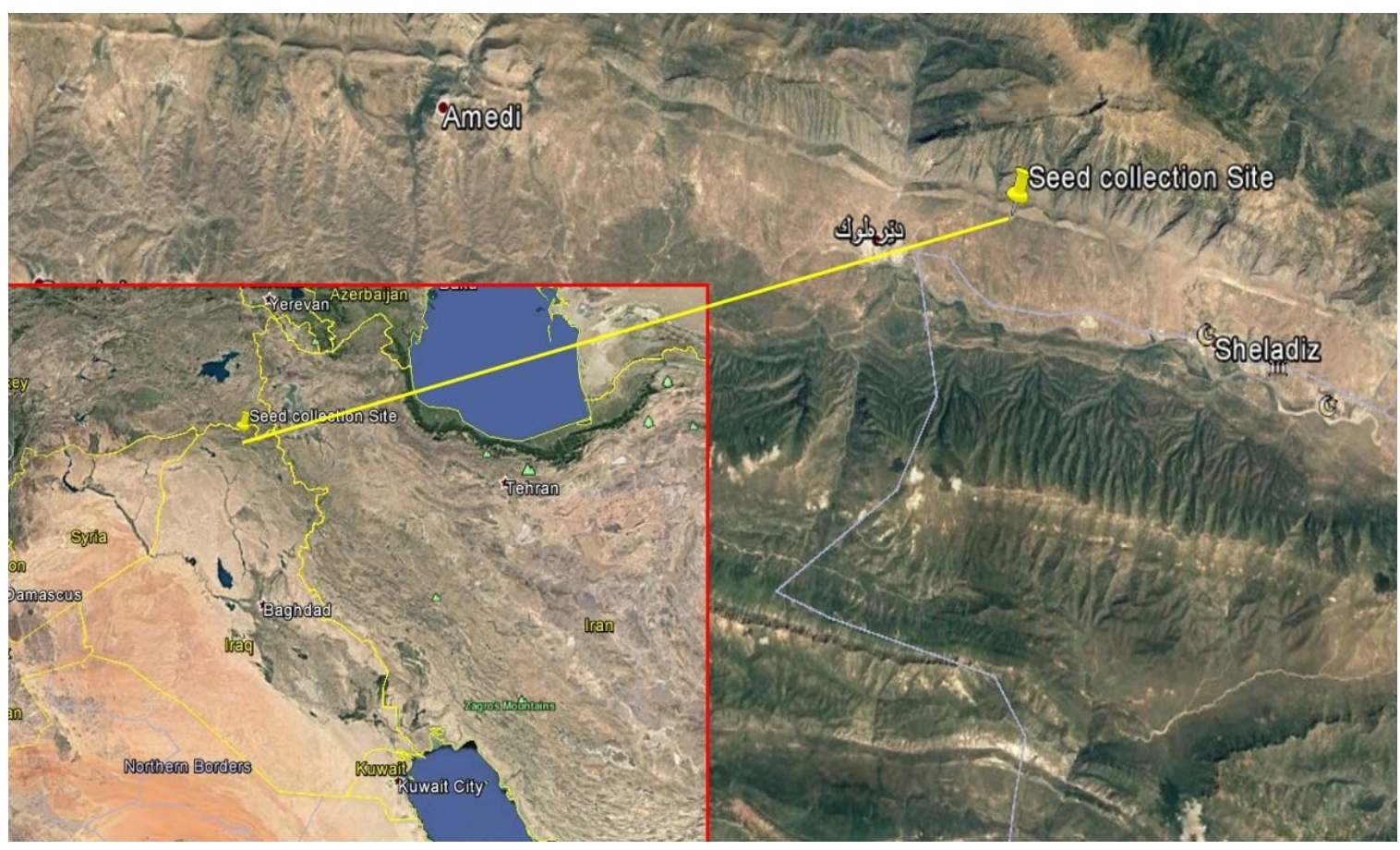

Fig. (2): Seed Collection Site, Deralok District, Duhok province - Kurdistan Region-Iraq

\section{Statistical analysis}

The research was managed and controlled in a field of Agriculture College and arranged in completely random factorial design by dividing 1100 seeds on 4 replication groups of each treatment. Then the data was analyzed by analysis of variance (ANOVA table) and Student-Newman-Keuls test using R-system program (R Development Core Team, 2017). For managing seed germination and seedling emergence Microsoft office (excel) has been used.RESULTS AND DISCUSSION

The results showed that there was a significant difference between the treatments. 


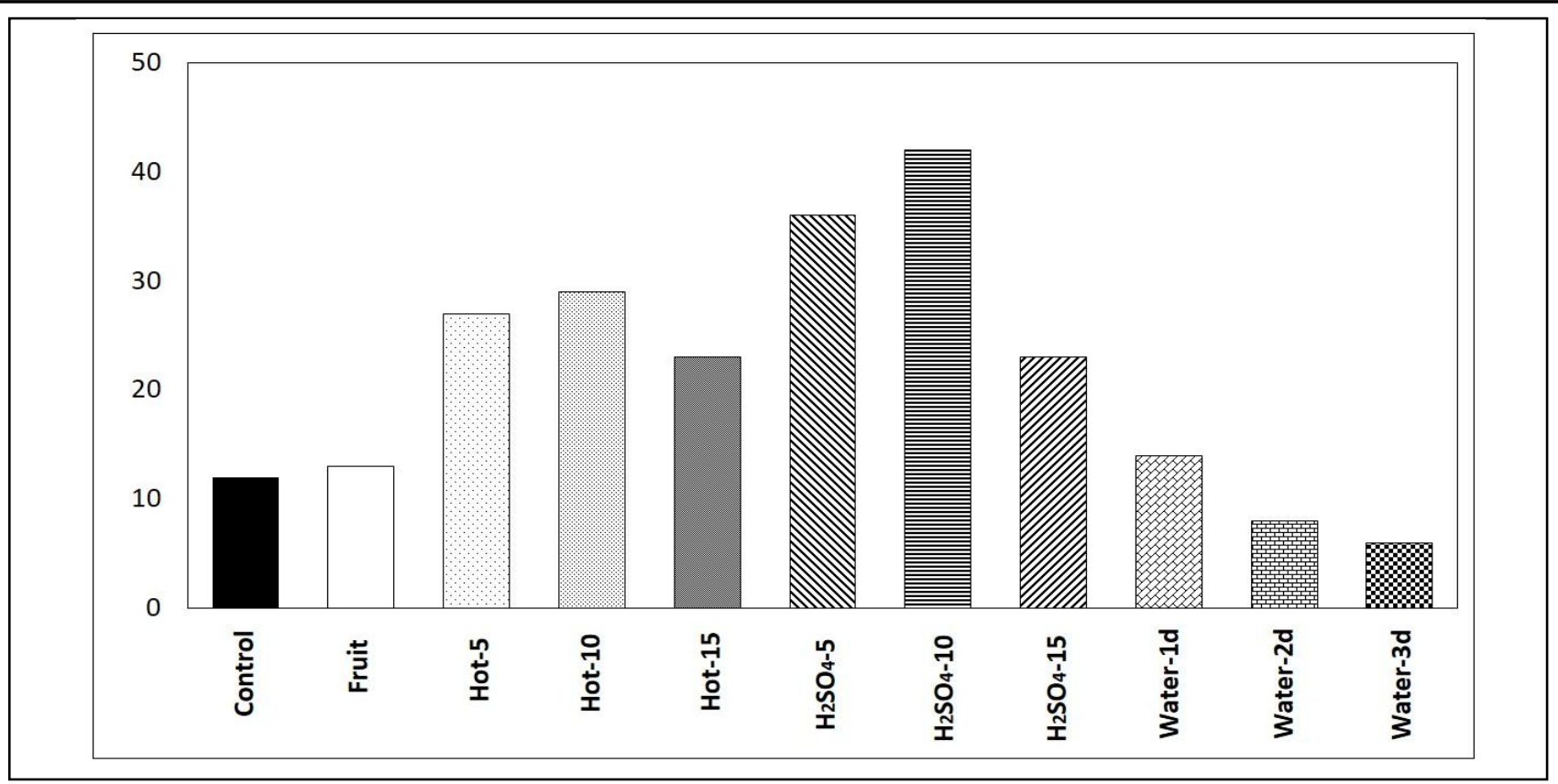

Fig. (3):Treatments and seed germination percentage of $P$. eurycarpa

\section{Pistacia eurycarpa}

The dormancy of seed might be inferred from embryo itself or tissues that enclosing embryo (Bewley and Black, 1994).There was low percentage of seed germination of Pistacia spp. due to hard endocarp that covered the seed (Isfendiyaroglu and Ozeker, 2002). The results demonstrated to no germination\% difference between fruits $(13 \%)$ and control $(12 \%)$. While there was differences in seed germination percentage due to hot water $(5,10$ and 15 minutes) $(27 \%, 29 \%$ and $23 \%)$ respectively, it is recognizable that the percentage of seed germination reduce at 15 minutes soaking in hot water this was attributed to seed embryos death due to duration of boiling water (Salih et al., 2016). Hot water could improve the germination percentage which leads to soften the seed coat to obtain water and exchanging gases (MohamedYaseen et al., 1994). Such chemical scarification in agreement with that of Ahoton et al., (2009) who reported that there a significant improvement of seed germination with scarification, hence it consisted the fast tegument inhibition of the seeds and the water entry in the reserves that help initiating of the embryo metabolic reaction. Moreover, in general the effect of $\mathrm{H}_{2} \mathrm{SO}_{4}$ was greater than other treatments as mentioned by (Ellis et al., 1985; Dirr and Heuser, 1987; Cole, 1994; Mackay et al., 1995; Kafkas and Kaska, 1998), this is because of the exocarp of Pistachio species (Ellis et al., 1985; Isfendiyaroglu and Özeker, 2002). Which lead to soften that hard coats and the germination rate after soaking in $\mathrm{H}_{2} \mathrm{SO}_{4}(5,10$ and 15 minutes) was $(36 \%, 42 \%$, and $23 \%$ ) subsequently (Figure 3).////The germination percentage of 10 minutes soaking in $\mathrm{H}_{2} \mathrm{SO}_{4}$ was better by $42 \%$ that 5 to 15 minutes and this is suggested by (Ellis et al, 1985 and Baskin and Baskin 2014). As well as, there was improvement of Pistacia spp. seed germination by treating seeds with chemical scarification (Ak et al., 1995). While there was a declining in rate of germination after 15 minutes soaking in $\mathrm{H}_{2} \mathrm{SO}_{4}$, this might be because the Acid enters inside the seeds which lead to kill the embryo. In comparison to control there was no significant impact of immersing seeds in Water for $(1,2$ and 3 days) which were $(14 \%, 8 \%$ and $6 \%$ ) (Figure 3 ). 


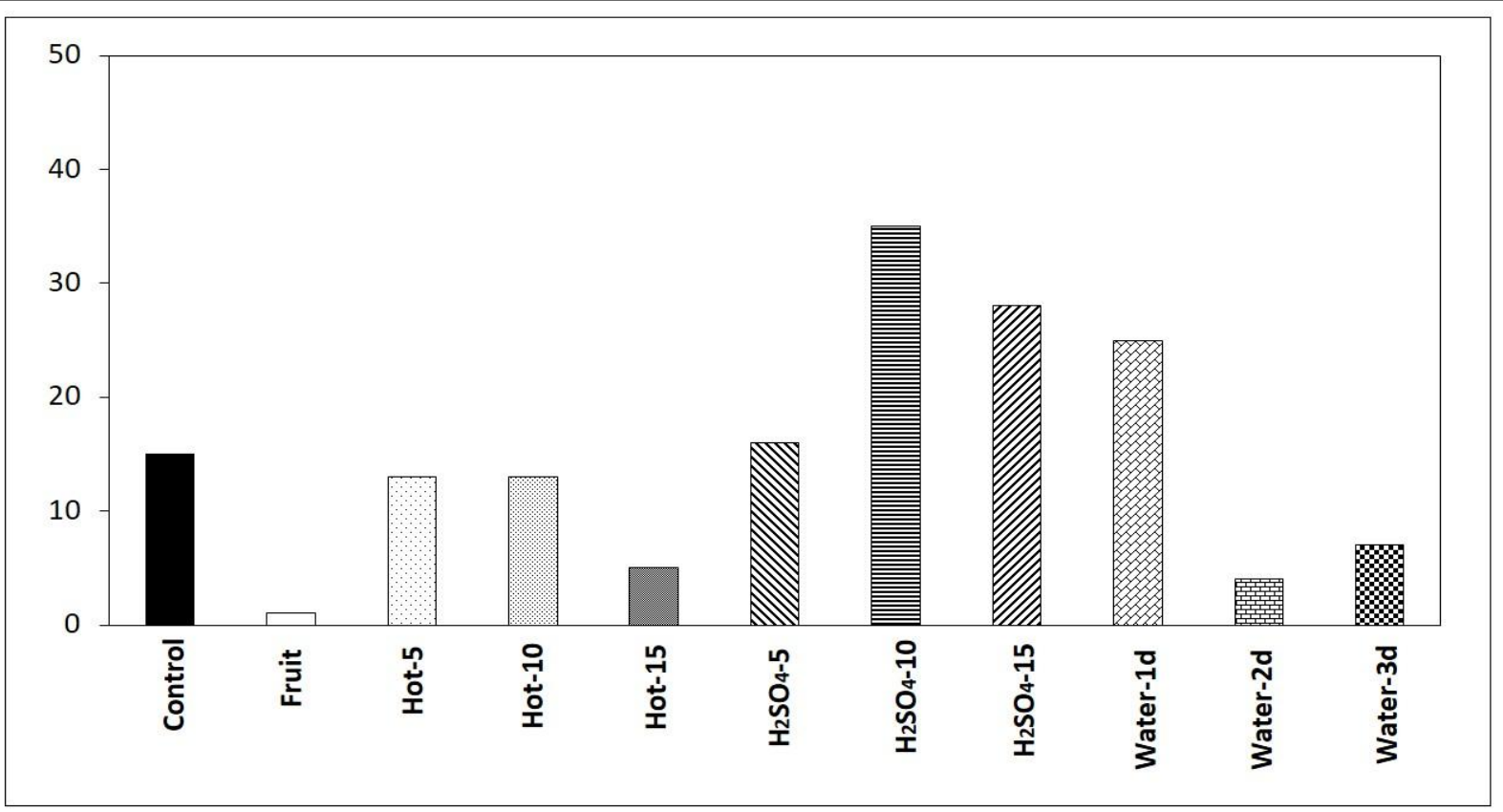

Fig. (4): Treatments and seed germination percentage of P. Khinjuk Pistacia khinjuk

The dormancy of seed might be inferred from embryo itself or tissues that enclosing embryo (Bewley and Black, 1994). The results revealed that the germination rate for sown fruit with exocarp was insignificant because of the turpentine substance which is exist in the outer layer of pistachio seeds (Bozorgi et al., 2013)that might kill the embryo. Furthermore, there was no significant difference of seed germination percentage of using hot water $(5,10$ and 15 minutes) $(13 \%, 13 \%$ and $5 \%)$ respectively; comparing to control (15\%), it is recognizable that the percentage of seed germination reduce at 15 minutes soaking in hot water this might be because of some seed embryos died due to duration time of boiling (Salih et al., 2016), Hot water could improve the germination percentage which leads to soften the seed coat to obtain water and exchanging gases (Longer and Degago, 1996). Moreover, in general the effect of $\mathrm{H}_{2} \mathrm{SO}_{4}$ was greater than other treatments as mentioned by (Ellis et al., 1985; Dirr and Heuser, 1987; Cole, 1994; Mackay et al., 1995; Kafkas and Kaska, 1998), this is because of the hard coats of Pistachio species (Ellis et al., 1985; Isfendiyaroglu and Özeker, 2002). Which lead to soften that hard coats and the germination rate after soaking in $\mathrm{H}_{2} \mathrm{SO}_{4}$ (5, 10 and 15 minutes) was $(16 \%, 35 \%$, and $28 \%$ ) subsequently (Figure 4).//I///It was obvious that the germination percentage of 10 minutes soaking in $\mathrm{H}_{2} \mathrm{SO}_{4}$ was better by $35 \%$ than 5 to 15 minutes and this was confirmed by (Abu-
Qaoud, 2007). The results are in agreement with the results of Ahoton et al., (2009) who reported that there was significant improvement of seed treated with scarification, hence it consisted the fast tegument inhibition of the seeds and the water entry in the reserves that help initiating of the embryo metabolic reaction. As well as, P. khinjuk seed germination was improved by treatment with acid scarification with dehulled applications (Acar et al., 2017). In contrasts the study of (Kafkas and Kaska, 1998) stratification was the best treatment to achieve highest germination percentage. While there was a declining in rate of germination after 15 minutes soaked in $\mathrm{H}_{2} \mathrm{SO}_{4}$, this might attributed to harmful of acid. In comparison to control there was no significant impact of the seeds in Water for (1, 2 and 3 days) which were $(25 \%, 4 \%$ and $7 \%)$ (Figure 4).

\section{CONCLUSION}

The purpose of this experiment is to investigate effect of pre-treatment on germination rate of $P$. eurycarpa and $P$. khinjuk seeds where both tree species native to Kurdistan region. The study findings on pistachio species were demonstrated that scarified seeds chemically with $\mathrm{H}_{2} \mathrm{SO}_{4}(10$ minutes) have a best germination rate for both Pistacia tree species. Furthermore, the results highlighted that other pre-treatment such as hot water on seeds germination of Pistacia eurycarpa. But there was no impact on seed germination rate 
of Pistacia khinjuk. For the first time fruits with exocarp had been used to test the germination percentages but there was no effect on seed germination for $P$. khinjuk whereas, the fruits with exocarp had a slight influence on seed germination of $P$. eurycarpa. The research suggested to achieve a optimal seed germination from hard seed coat required soaking seeds scarified chemically with Sulfuric acid it is important to conduct a researches on seeds that had hard exocarp. This study has achieved to find out a new cultivation method of pistachio in Kurdistan Region. Therefore, this research will serve as a base for future studies and investigations in issue of economic botany and improvement of the rural Kurdish livelihood activities.

\section{REFERENCES}

-Abu-Qaoud, H. (2007). Effect of scarification, gibberellic acid and stratification on seed germination of three Pistacia species. AnNajahUniv J Res (N Sc), 12, 1-11.

- Acar, I. Yasar, H. And Ercisli, S. (2017). Effects of dormancy-breaking treatments on seed germination and seedling growth of Pistacia khinjuk Stocks using as rootstock for pistachio trees. Journal of Applied Botany and Food Quality, 90: 191-196.

- Ahoton, L.E., J.B. Adjakpa, M' , Po. M’ . Po. Ifonti and E.L.Akpo. (2009). Impact of seed pretreatment on germination of Prosopisafricana (Guill., Perrot. et Rich.)Taub. (Césalpiniacées).Tropicultura, 27(4): 233-238.

- AK, B.E., Ozguven, A.I., Nikpeyma, Y., (1995) the effect of $\mathrm{GA}_{3}$ applications on pistachio nut seed germination and seedling growth. Acta Hort. 419, 115-120.

- Baskin, J. M., \& Baskin, C. C. (2014). What kind of seed dormancy might palms have?. SeedScienceResearch, 24(01), 17-22.

- Bewley, J. \& Black, M. (1994). Seeds Physiology of developmentand germination.Plenum Press. New York.

- Bozorgi, M., Memariani, Z., Mobli, M., SalehiSurmaghi, M. H., Shams-Ardekani, M. R., \&Rahimi, R. (2013). Five Pistacia species ( $P$. vera, $P$. atlantica, $P$. terebinthus, $P$. khinjuk, and $P$. lentiscus): a review of their traditional uses, phytochemistry,andpharmacology. The Scientific World Journal.

- Chaabouni, A.C. \& Gouta, H. (2002). Effect of chemical scarification and Gibberellic acid on in vitro germination of Pistacia atlantica seeds. Acta Horticulturae. (591). 73-76.
- Chebouti-Meziou, N., Merabet, A., Chebouti, Y., Bissaad, F., Z., Behidj-Benyounes, N., \& Doumandji, S. (2014). Effect of cold and scarification on seeds germination of Pistacia atlantica L. for rapid multiplication. Pak. J. Bot., 46(2): 441-446

- Cole, J. C. (1994). Increased germination through pregermination treatments of Chinese pistache seeds. Journal of production agriculture, 7(1), 116-119.

- Crane, J.C. \& Forde, H.I. (1974). Improved Pistacia seed germination. California Agriculture. (28). 9.

- De Rougemont, G. M. D. (1989). Field guide to the crops of Britain and Europe.London, Collins Press.

- Dirr, M., \&Heuser, C. W. (1987). The reference manual of woody plant propagation: from seed to tissue culture: a practical working guide to the propagation of over 1100 species, varieties and cultivars. Varsity Press. 239.

- Ellis, R. H., Hong, T. D., \& Roberts, E. H. (1985).Handbook of seed technology for genebanks.v.2: Compendium of specific germination information and test recommendations. Handbooks for Genebanks (IBPGR). 405.

- Fatahi, M. (1996). The esploitation from wild pistachio trees in kordestan. First National Symposium on BenehIlam, Iran.

- Isfendiyaroglu, M. \&Özeker, E. (2002). The relation between phenolic compounds and seed dormancy in Pistaciaspp. In Ak B.E. (ed.). 11 GremaSerr pistachios and almonds.Chieres Options Mediterraneennes. (56). 227-232.

- Isfendiyaroglu, M., and Ozeker, E. (2001). The relations between phenolic compounds and seed dormancy in Pistacia spp. XI GREMPA Seminar on Pistachios and Almonds. Cahiers Options Méditerranéennes 56, 227- 232.

- Jeffrey C. (1980). Anacardiaceaein:Townsend C.C.\&E.Guest; Flora of Iraq, Volume 4 Part one: Cornaceae to Rubiaceae.-Ministry of Agriculture and Agrarian Reform, Iraq: 486499.

- Kafkas, S. and Kaska, N. (1998). The effect of scarification, stratification and $\mathrm{GA}_{3}$ treatments on the germination of seeds and seedling growth in selected P. khinjuk types. Acta Horticulturae. (470). 545-459

- Kaska, N. (2001). Almond and Pistachio in the Mediterranean countries.III International Symposium on Pistachios and Almonds.Zaragoza. Spain. 
- Linne, C. V. (1753). Species plantarum: 641. Paris, France.

- Longer, D.E. and Y. Degago (1996).Field weathering potential of normal and hardseeded soybean genotypes.Seed Science and Technology, 24: 273-280.

- Mackay, W. A., Davis, T. D., \& Sankhla, D. (1995). Influence of scarification and temperature treatments on seed germinationof Lupinushavardii. Seed science and technology, 23(3), 815-821.

- Mittermeier, R. A. (2004). Hotspots revisited. Cemex.

- Mohamed-Yaseen, Y., S.A. Barringer, W.E. Splittstoesser and S. Costanza (1994). The role of seed coats in seed viability.The Botanical Review, 60: 426-439.

- Padulosi S. and A. Hadj-Hassan, (2001). Project on Underutilized Mediterranean Species. Pistacia:towards a comprehensive documentation of distribution and use of its genetic diversity in Central \& West Asia,North Africa and Mediterranean Europe. Report of the IPGRI Workshop, 14-17 December 1998, Irbid, Jordan.

- Peel, M. C., Finlayson, B. L., \& McMahon, T. A. (2007). Updated world map of the KöppenGeiger climate classification. Hydrology and earth system sciences discussions, 4(2), 439473.

- Raeder-Roitzsch, J.E. (1969). Forest trees in Iraq. College of Agriculture, University of Mosul, Iraq.

- R Development Core Team (2017).R: ALanguage and Environment for Statistical Computing. R
Foundation for Statistical Computing, Vienna, Austria.

- Salih, T.W.,Nazar,M. S., Gailan, B. A., and Hameed, A. R. (2016). Effect of soaking periods in sulfuric acid and sowing media on germination of Rhus coriaria L. seeds under field conditions. Journal of University of Duhok, (19)1: 288-294

- Shahbaz, S. E. (2010). Trees and Shrubs, A field guide to the trees and shrubs of Kurdistan region of Iraq.Journal of university of Duhok.

- Sharifi, M.S. (2014). Pistacia atlantica Kurdica, the Kurdish Medicinal Plant. In: Heshmati, A., Dilani, A., \&Baban, S. M. (Eds.). Perspectives on Kurdistan's Economy and Society in Transition: Volume II (Vol. 2). Cambridge Scholars Publishing. PP. 64-83.

- Thakur, B.S. \&Rathor, D.S. (1991). Pistachio. In: Temperate Fruits. Mitra, S.K., Bose, T.K., \& Thakur, D.S. (Eds.); Horticulture and Allied Publisher, Calcutta, India.

- Townsend C.C.\&E.Guest (1980). Floraof Iraq, Volume 4 Part one: Cornaceae to RubiaceaeMinistry of Agriculture and Agrarian Reform, Iraq.

- Youssef, S., Mahmood, A., Mahdi, H., and Vela, E., (2015). New contribution on Orchids (Orchidaceae) of Duhok Province in Kurdistan Region (N-Iraq). Journal Europäischer Orchideen, 47, pp. 405-420.

- Youssef, S.,Vela, E.,Galalaey, A., Mahmood, A.,Mahdi, H., (2017). Illustrated wild orchids as a scientific window on the unexpected nature of the Kurdistan Region areas (NW Zagros). (In Edit) 


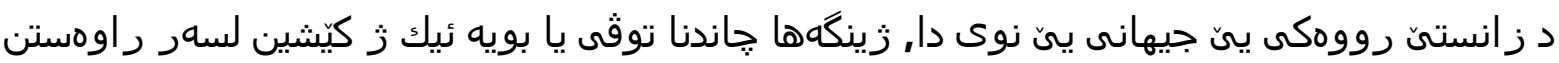

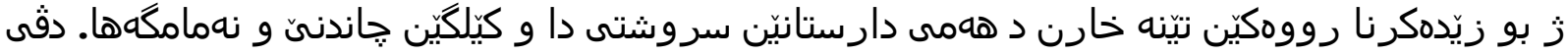

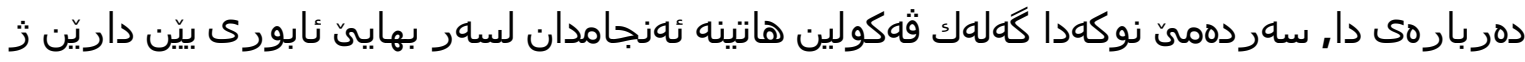

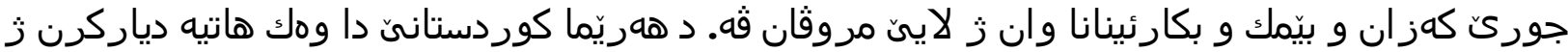

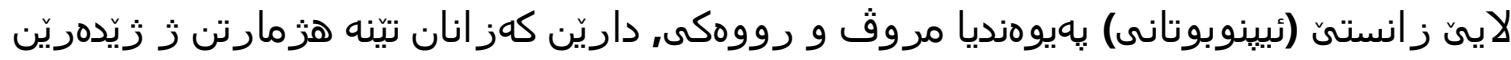

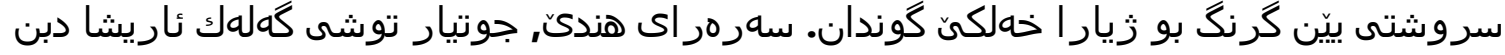

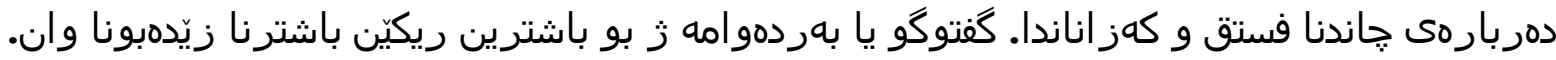

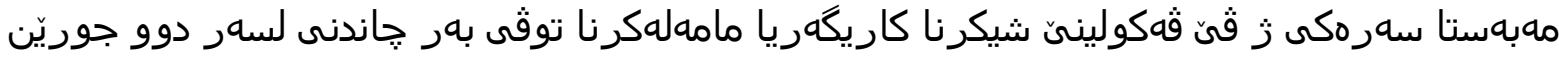

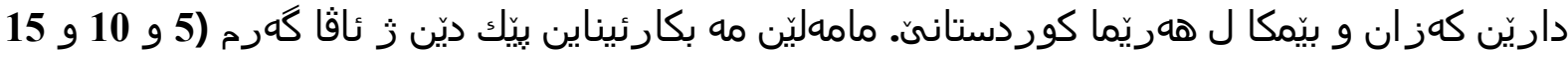

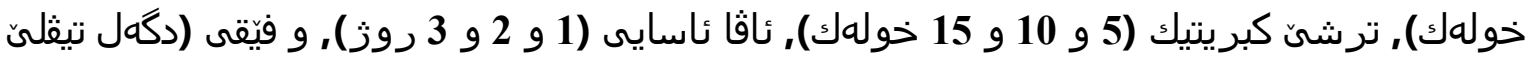

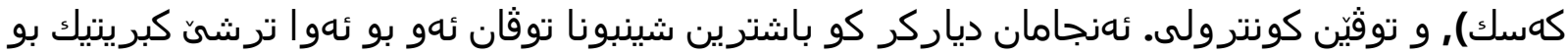

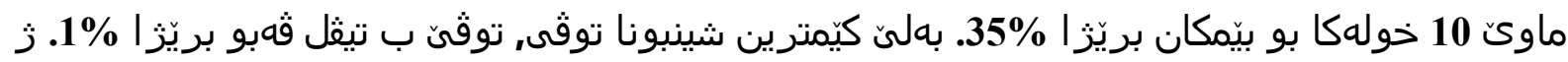

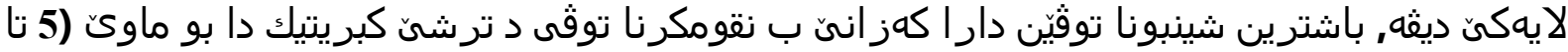

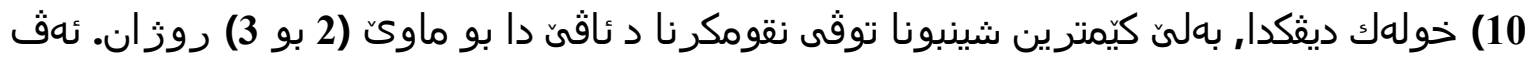

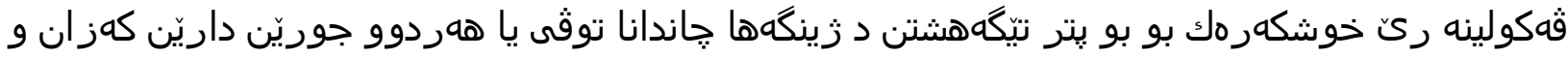

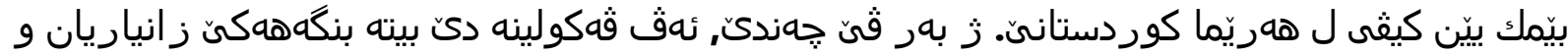

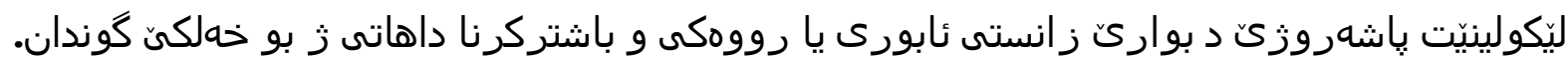




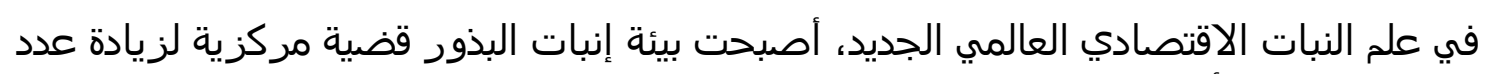

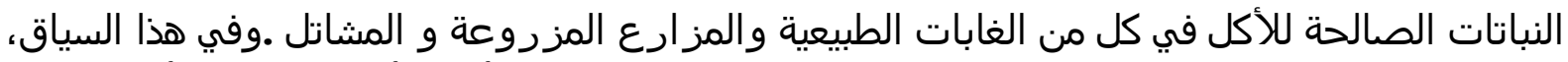

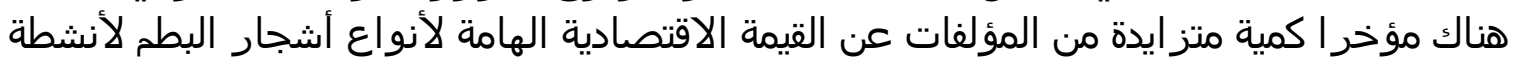

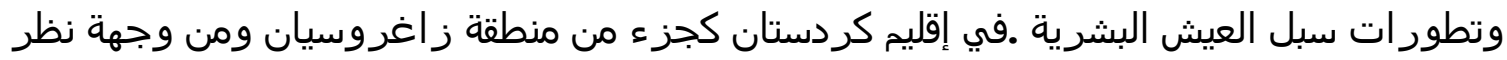

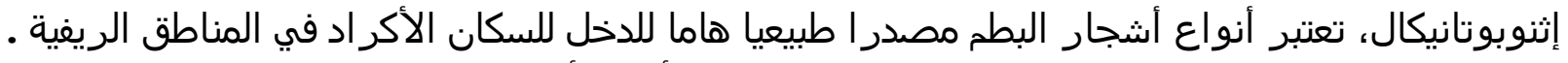

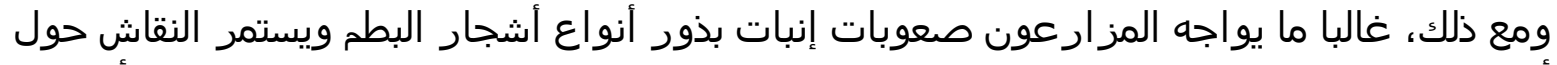

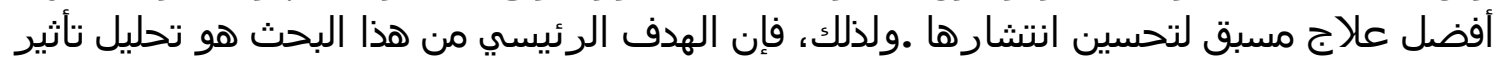

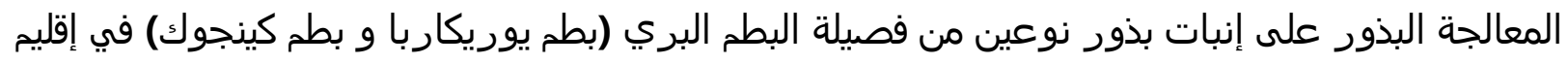

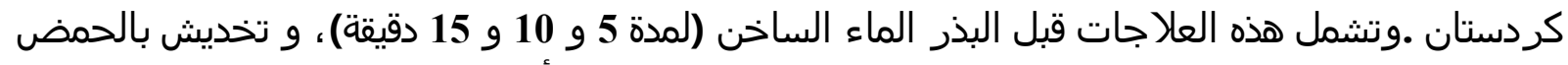

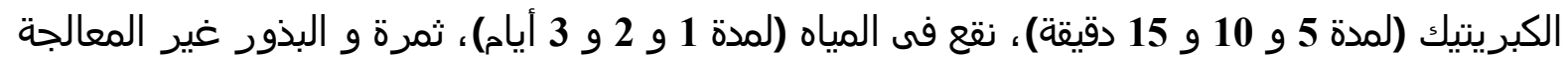

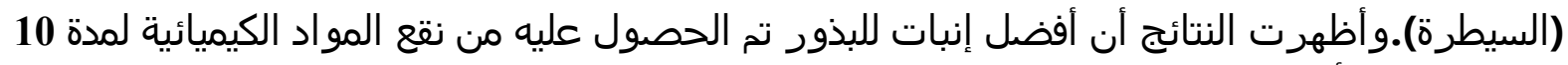

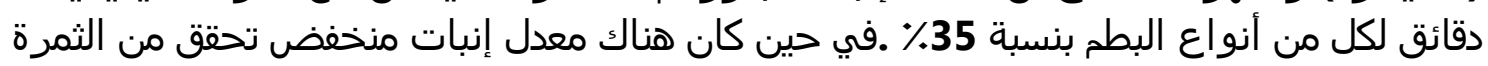

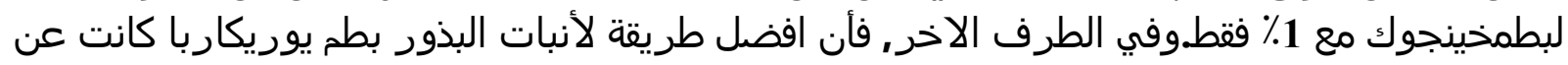

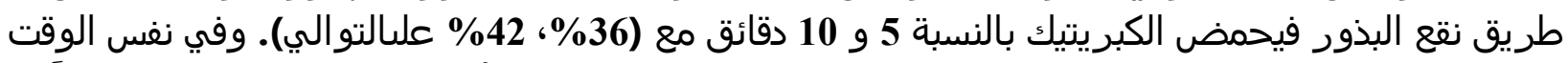

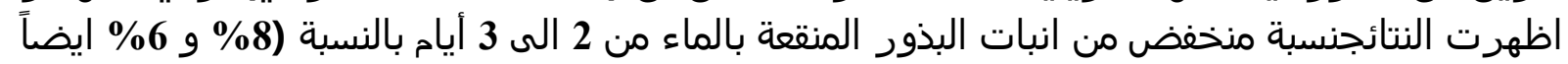

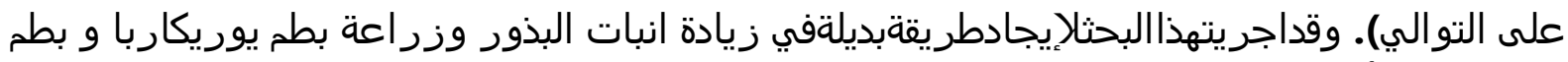

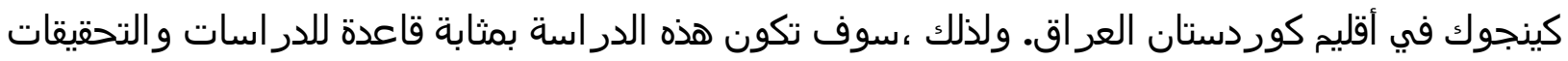
المستقبلية في قضية علم النبات الاقتصادي و تحسين أنشطة كسب العيش الدئ الكردية في الأرياف. 